\title{
INVESTIGATING THE ENGLISH SYLLABUS OF ROOM DIVISION DEPARTMENT RELATED TO THE NEEDS OF THE HOTEL INDUSTRIES: A CASE STUDY AT ONE TOURISM INSTITUTE IN BANDUNG
}

\author{
Nuraeni Handayaningrum \\ Budi Setiawan \\ Sekolah Tinggi Pariwisata Bandung (STP Bandung) \\ Korespondensi: Jln. Dr. Setiabudhi 186 Bandung 40154 \\ Pos-el: ningrum_0312@yahoo.com
}

\begin{abstract}
Investigating the English Syllabus of Room Division Department Related to the Needs of the Hotel Industries: A Case Study at One Tourism Institute in Bandun g. This study investigates what English syllabus needed by the first year students of $\mathrm{R}$ oom Division Department in one tourism institute in Bandung. In this study, three hot els, 35 fifth semester students of Room Division Department and one English lecturer were involved. The purpose of this study is to find out the Room Division students' $n$ eeds in learning English after that to try to propose a new syllabus. The data were coll ected through questionnaire to the students, interviews with the Front Office Manager of three prestigious hotels in Bandung and one English lecturer. Data from questionna ire and interview were coded and categorized based on the students and hotels' respo nses to their needs. The result of this study indicates that there are some shortages of English materials and syllabus that contribute to the students' performance of English during their job training. Therefore, the writer tries to propose a new syllabus for Roo $\mathrm{m}$ Division Department in this tourism institute.
\end{abstract}

Keywords: ESP, syllabus design, Room Division.

\begin{abstract}
Abstrak
Investigasi Silabus Bahasa Inggris Divisi Kamar terkait Kebutuhan Industri Pe rhotelan: Studi Kasus di salah satu Institut Pariwisata di Bandung. Studi ini me nginvestigasi silabus Bahasa Inggris yang dibutuhkan oleh mahasiswa tahun pertama program studi Divisi Kamar di salah satu institut pariwisata di Bandung. Studi ini me libatkan 3 hotel, 35 mahasiswa program studi Divisi Kamar semester 5 dan 1 dosen bahasa Inggris. Tujuan dari studi ini adalah untuk mengetahui kebutuhan bahasa Ing gris mahasiswa program studi Divisi Kamar dan juga mencoba mengajukan silabus baru. Data diperoleh melalui kuesioner kepada para mahasiswa, interview dengan $\mathrm{Fr}$ ont Office Manager dari tiga hotel di Bandung dan satu dosen bahasa Inggris. Data d ari kuesioner dan interview dikategorikan berdasarkan respon yang diberikan oleh pa ra mahasiswa dan Front Office Manager. Hasil penelitian yang didapat mengindikas ikan adanya kekurangan pada materi dan silabus bahasa Inggris yang turut berkontri busi dalam performa mahasiswa dalam menggunakan bahasa Inggris. Berdasarkan d ata tersebut, peneliti mengajukan silabus baru untuk program studi Divisi Kamar pad a institut pariwisata tersebut.
\end{abstract}

Kata kunci: ESP, rancangan silabus, Divisi Kamar. 


\section{INTRODUCTION}

Tourism is one economic sector th at supports the economic development in a country or a region. English as the internat ional language is a main language that sho uld be taught in the tourism schools. There fore in order to function professionally in English, students need not only an underst anding of the language system but also an awareness of how to implement it effective ly and appropriately.

Sekolah Tinggi Pariwisata Bandun $\mathrm{g}$ (STP Bandung), as one of the institutes managed by the Ministry of Tourism and Creative Economy, emphasizes the foreign language subject especially English that sh ould be intensely executed in the students $t$ eaching and learning process. There are thr ee departments in STP Bandung, namely $\mathrm{H}$ ospitality Management, Tours and Travel Management, and Tourism Management. Each departments are devided into several study programs such as Hotel Administrati on, Room Division, Food and Beverage, F ood Production, Bakery and Pastry Produc tion, Tour Business Management, Tour Bu siness Management, Business Convention Management, Tourism Destination Manag ement and Tourism Business Management.

Focusing on tourism and all its asp ects, the approach of English language teac hing in STP Bandung is English for Specif ic Purposes (ESP). Hutchinson \& Waters ( 1995:16) devide ESP into two types accor ding to whether the learners require Englis $\mathrm{h}$ for academic study, namely EAP: Englis $\mathrm{h}$ for Academic Purposes or for work and EOP/EVP: English for Occupational Purpo ses or English for Vocational Purposes. Th e ESP course design process should procee $d$ by first identifying the target situation an $\mathrm{d}$ then carrying out a rigorous analysis of $\mathrm{t}$ he language features of that situation Hutc hinson \& Waters (1995:2). The researcher finds out that English is still one of the diff icult subjects for the students in this touris $\mathrm{m}$ school. Many students still do not have self-confidence in practising English in the ir daily activities, especially in their practic al week. Furthermore, based on the writer' s informal talk with the Front Office Mana ger of one prestigious hotel in Bandung, th e phenomenon actually happened in severa 1 hotels in Indonesia and it is very crucial s ince people worked in hotel should able to speak English, especially for those who wo rk in front office department. They will be the first person who have direct interaction when guests come.

From the phenomenon above, the writers are interested in finding out the act ual needs of hotel industry at English lang uage and then matching it to the English sy llabus used in STP Bandung. As Kaur (200 7) states that ESP teacher needs to be mind ful of developing courses that are learner-c entered and help to meet the English langu age needs of their learners. For this study, related to the phenomenons occur, the writ ers are also interested to find out the needs of English competence as perceived by stu dents, lecturers, and hotel management, th en the writer is going to investigate the rel evance of English syllabus of Room Divisi on Department in STP Bandung to the nee ds of hotel industry. Room Division Depar tment is the department, which is focuses o $\mathrm{n}$ front office and housekeeping area and $\mathrm{t}$ he graduates are expected to become the fr ont liners in the hotel industries.

As the result, this study is expected to find out the kinds of English competenc es needed by the Room Division students a s perceived by students, lecturers, and hote 1 management and also to find out whether the English syllabus of this tourism school is relevant to the needs of the hotel, therefo re later on the graduates will be able to app ly their English skills in the hotel properly.

English for Specific Purpose, or ES $\mathrm{P}$ for short, is an approach to language lear ning in which the syllabus, contents and $\mathrm{m}$ ethods are determined according to the nee ds of learners' specialized subjects. It is not a particular kind of language or methodolo gy. ESP is an approach to language learnin $\mathrm{g}$, which is based on learners' needs (Hutc 
hinson and Waters, 1995: 19). For DudleyEvans and St. John (1988:4-5), ESP teachi ng has its own methodology. They define ESP in absolute and variable characteristic $\mathrm{s}$, which means that ESP is designed to me et specific needs of the learners or related $t$ o specific disciplines, applied a different $\mathrm{m}$ ethodology from General English and it is designed for adult learners. Strevens (1988 , pp.1-2 as cited in Gatehouse (2010) defin es the absolute characteristics of ESP as be ing (1) designed to meet specified needs of the learner (2) related in content (in its the mes and topics) to particular disciplines, $o$ ccupations and activities (3) centered on th e language appropriate to those activities i n syntax, lexis, discourse, semantics, etc.a nd analysis of this discourse (4) in contrast with General English.

Hutchinson \& Waters (1995:10-14) state that there are five phases of ESP deve lopment:1) register analysis 2) discourse a nalysis 3) target situation analysis 4) skills and strategies. Among those phases above, the writer's concern is on the target situati on analysis. It is stated above that in target situation analysis; the purpose of an ESP c ourse is to enable learners to function adeq uately in a target situation. Meaning that th e learners will be able to use the language $\mathrm{i}$ $\mathrm{n}$ a certain situation they are going to work with. Therefore the ESP course design sho uld proceed by identifying the target situati on first, and then carrying out a rigorous a nalysis of the linguistic features of that situ ation. The process is usually known as nee $\mathrm{d}$ analysis (1995:12).

Needs analysis is an important part in designing and carrying out any language course. According to Iwai et al. (1991) as cited in Songhori (2008), the term needs a nalysis generally refers to the activities tha $t$ are involved in collecting information tha $t$ will serve as the basis for developing a cu rriculum that will meet the needs of a parti cular group of students. In the language-ce ntered approach, needs is the ability to co mprehend and/or produce the linguistic fea tures of the target situation (Hutchinson an d Waters, 1995: 54). For Richards, ESP lea rner's needs are often described in terms of performance or what the learner will be abl e to do with the language at the end of a co urse of the study (2002:33). Furthermore, he points out that an important principle of ESP approaches to language learning is tha $t$ the purposes for which a learner needs a 1 anguage rather than a syllabus reflecting th e structure of general English should be us ed in planning an English course. Therefor e, learners' needs are often described in ter $\mathrm{m}$ of performance, of what the learner will be able to do with the language at the end of the course.

Richards (2002:152) states that ther e are several types of syllabus, namely a) $s$ ituational syllabus b) topical syllabus c) fu nctional syllabus d) task-based syllabus. In this study, it seems that situational syllabu $\mathrm{s}$ will be appropriate to be applied since sit uational syllabus identifies the situation in which the learner will use the language an $\mathrm{d}$ the typical communicative acts and the la nguage used in that setting (2002:156).

From the definition of each syllabu s design above, it is clearly stated that need analysis is needed and is important before designing the syllabus of an ESP course. $\mathrm{N}$ unan (1989:25) suggests that an analysis of the language, information about the learner , beliefs about the learning process itself, $o$ $r$ combination of them can be the starting $p$ oint in syllabus design. In other words, nee ds analysis is the starting point of syllabus design. (Ibid, p. 79) states that the next ste $\mathrm{p}$ is defining goals. Goals can be derived $\mathrm{b}$ y syllabus designers through a process of $i$ ntrospecting on the sorts of communicative purpose for which the language is used. Af ter that, selecting content and grading. The $\mathrm{n}$ selecting and grading learning tasks and activities. Finally, is selecting and grading the objectives.

In this study, it seems that situation al syllabus will be appropriate to be applie d since it is line with Richards (2002:156) 
where situational syllabus identifies the sit uation in which the learner will use the lan guage and the typical communicative acts and the language used in that setting. Whil e Krahnke (1987:45) argues about the posi tive and negative characteristics of situatio nal syllabus. He mentions the negative cha racteristics of situational syllabi is tend to 1 ead the learners to rely on pre-learned routi nes and patterns of language use rather tha $\mathrm{n}$ creative and negotiated uses of language therefore it may interfere the productive la nguage learning. Despite the negative char acteristics, it is still believed that situationa 1 syllabi can lead more directly to learner's ability to communicate in specific settings and the use of situations in language teachi ng can help to provide some social and cul tural information about the language and it s users in a non-didactic way (Ibid, p. 45-4 $6)$. Therefore, the writer also believes that situational syllabus is still relevant to be di scussed in this study.

However, in designing the ESP cou rse the situational syllabus is regarded insu fficient. In ESP course design, topical sylla bus, functional syllabus, and task-based syl labus are also needed. Basically, all kinds of syllabus have some similar and distincti ve features. What is needed in this study is to accommodate those particular strengths in each syllabus to enrich English syllabus development in this tourism institute.

\section{METHOD}

The participant of this study is iden tified as the hotel, the English lecturer and 35fifth semester students of Room Divisio $\mathrm{n}$ department. In order to get the optimum result of the research, there will be no sam pling taking but it will be done by census $t$ echnique. As the user of the students, three hotels in Bandung will be taken as respond ents since most of the students are doing th eir job training there. The hotels are $\mathrm{H}, \mathrm{T}$, and SHT.

For the student participants, the po pulation will be 35 fifth semester students o f Room Division department that have just completed their job training in the hotel for six months. Besides, the writers will take $d$ ata from one of English lecturers at Room Division department. The writers are famil iar with and have the access to this school since the writers have been teaching there $f$ or more than eight years and one of the wri ters was used to handle the job training to $t$ hose hotels. Therefore the writers are easy to collect the data.

The data collection techniques that are used in this study namely questionnaire $\mathrm{s}$ and interview.

a) Questionnaire

The questionnaire will be given to all fi fth semester students (35 students) of Roo $m$ Division Department by using the censu s technique. Fifth semester students are sel ected since they have completed their Supe rvised Field Training or job training in hot el industry, meaning that they already expe rienced the real hotel-life. Therefore, it is $h$ oped that they can give clear picture of wh at is needed by front liners in the hotel. For this study, the writers are going to use ope n-ended questionnaire form in order to exp lore the information from the participants deeper. The data from questionnaire will $b$ e coded. After that the data will be categori zed according to the responses obtained in this study.

b) Interview

The interview will be conducted with $t$ he Front Office Manager or the Training Manager of the selected hotels and one of $t$ he English lecturers in STP Bandung. The interview will take about twenty to thirty minutes for each participant and it is condu cted to clarify the questionnaire and docu ment analysis, therefore the data obtained $\mathrm{i}$ $\mathrm{n}$ this study will be valid. The data from in terview will be recorded. For this study, th e writers will use semi-structured intervie w. By using this kind of interview, it is ho ped that the writers will be able to conduct in depth interview. 


\section{RESULTS AND DISCUSSION}

Front office as one of departments in Roo $m$ Division has the greatest amount of gues t contact. It is located in the busiest area of the hotel's lobby. Kappa et.al (1990:39-43) stated that front office department usually consists of several sections such as front $d$ esk agent, reservation agent, switchboard o perator, front office cashier, night auditor, and concierge. Those sections have their o wn specific job description as follows:

a) Front desk agent. A front desk agent typically performs pre-registration activities.

b) Reservations agent. A reservation agent typically monitors and responds appropriately to guest, travel agent, and referral network communications concerning reservations.

c) Switchboard operator. They usually answer incoming calls; direct calls to guestrooms through the switchboard system.

d) Front office cashier. They deal with posts revenue center charges to guest accounts; receive payment from guests at check-out; coordinate billing of credit card and direct-billed guest accounts; balance accounts at the close of each shift; assume responsibility for cash used in processing front desk transactions.

e) Night auditor. The night auditor checks the accuracy of front office accounting records and compiles a daily summary of hotel financial data.

f) Concierge. A concierge typically provides direction and information to the guests; makes airplane, theater or other reservations tickets; organizes special functions and arranges secretarial services.

From the student's questionnaires and $\mathrm{t}$ he interview with the hotel's Front Office Managers and the English lecturer, the writ ers try to draw a framework of English co mpetences needed by the Room Division $\mathrm{s}$ tudents at STPB as follows:

a) English language is important and needed in hotel industry, especially for those who have direct contact with the guests.

b) Listening skill has become the major skill that should be possessed by the front liners since it is important to understand somebody else's need. It could create a mess if a front liner does not understand the guests' needs, supervisor's needs or even colleagues' needs. At the second place is speaking skill. In order to have a good communication, listening and speaking are both needed.

c) Job knowledge of front liners, communication skills, good grooming of attitude and appearance, enthusiasm, politeness and friendliness are the basic skills for front liners in the Front Office.

d) Specific English materials related to the job description of front liners are needed such as handling guests' reservation, handling check-in and check-out, telephoning and handling messages, handling complaint, describing hotel and rooms facilities, giving directions and so forth.

e) According to the students, TOEIC materials are the most suitable listening material for them. For speaking, the students point out roleplay as the most suitable technique in learning English. This is also supported by the lecturer's opinion. For reading, materials taken from the newspapers or magazines are suitable for the students since it could be related to the current issues of the industry. While for writing, the students expect to have free writing performance since they can express anything they wanted to express. 
f) Innovation in teaching and learning techniques of English and native speaker are strongly suggested by the hotel industry to enhance the students' ability in English especially for their listening and speaking ability.

g) The suggested assessment of English from the hotel industry is oral test. This is also in line with the students' expectation. They believe that the students' self-confidence to speak English could be encouraged through this kind of assessment. While for the English lecturer, both written and oral test are important. It would make the evaluation more valid since not all students were good in oral assessment and vice versa.

From the above information, the wr iters try to propose a new syllabus as follo ws. The basis of the proposed syllabus is $\mathrm{i}$ nformation from needs analysis. Needs ana lysis helps define the needs of the students, which are the used to state the goal of the $\mathrm{c}$ ourse. The goals of the course itself are the basis of developing other elements of the $\mathrm{c}$ ourse, which cover objectives, materials, le arning activities, and evaluation.

\section{Rationale}

An ESP syllabus for tourism stude nts especially for those majoring hotel, ma $\mathrm{y}$ contain the functional-situational, skill $\mathrm{b}$ ased and the task-based approach since it $\mathrm{i}$ s hoped to stimulate students' knowledge a nd purpose of learning English for their wo rkplace. Students should also be exposed $t$ o various elements of hospitality language as mentioned by Blue and Harun (2003). T he basic needs of English of the hotel indu stries has actually been accommodated by this tourism institute. However, there are s ome lacks occurred that become the focus of this study. Thus the writers suggest the syllabus to cover these needs as follows. $T$ his course is designed to prepare students with a number of workplace skills in the $h$ ospitality field, especially Room Division. The coverage of the course will deal with $t$ he skills, knowledge, and attitude required by personnel working in the hospitality ind ustry in a craft level. The skill is focused $i$ $\mathrm{n}$ this course since the data suggested that $\mathrm{t}$ he students need the skills. Knowledge of Room Division is important since the data also suggested that to be an hotelier the stu dents should know the knowledge. While a ttitude is needed since good service is the most important aspect in the hotel industry . Therefore, based on the skills, knowledge , and attitude mentioned above, the materia ls given will be greetings, introduction and farewell, hotel room, taking messages on $\mathrm{t}$ he phone, taking room reservation checkin $\mathrm{g}$ in and checking out the guests, giving dir ections inside and outside the building, ask ing and giving information and handling $\mathrm{c}$ omplaint both spoken and written.

\section{Objectives}

Based on the findings, the students have to actively communicate with the gue sts. Listening and speaking skills are very $i$ mportant for them since they are interrelat ed. Upon the completion of this course, the students are expected to (a) have more soli $d$ understanding and various skills of Engli sh for Room Division Department; (b) be a ble to appropriately communicate with the stakeholders in craft level in both spoken a nd written English.

\section{Materials}

ESP materials should provide expo sure to the specialized genres and register of ESP (Richards, 2002:252). Besides, We issinger (2002:52) argues that hotel or mot el front office generally performs several a ctivities namely processing advance reserv ation, registering and rooming guests, mov ing guests' luggage, issuing room keys, $\mathrm{pr}$ oviding information, handling guests' mail , administering telephone service, accounti ng (making payments and billing), and che cking out guests. Based on the objectives, $\mathrm{t}$ 
he students' lacks and the needs, the Engli sh materials provided should be related to hotel knowledge such as handling reservati on, handling check-in, telephoning, handli ng complaints, explaining hotel facilities, $s$ elling hotel products, etc. Those materials could be extracted from the newspaper, ma gazines, hotel brochures, Internet, and so o n.

The materials given in semester on e will be divided into the following section $\mathrm{s}$ : greetings, introduction and farewell, hot el room, taking messages on the phone, an $\mathrm{d}$ taking room reservation. The first section $\mathrm{s}$ are greetings, introduction and farewell. Those materials are given at the beginning of the course since good attitude and polite ness is important in hospitality field for ser vicing the guests. This is in line to Richard $\mathrm{s} \&$ Rodgers as they stated that competenci es consists of a description of the essential skills, knowledge, attitudes, and behaviors required for effective performance of a rea l-world task activity (2001: 144).

The second section is hotel room. Hotel rooms' knowledge is given before ro om reservation. The students need to have knowledge about hotel rooms (facilities, pr ices, etc) since they will have to explain th em when the prospective customers ask $a b$ out the hotel rooms' information before $\mathrm{m}$ aking room reservation. In this section, th e students are expected to be able to explai $\mathrm{n}$ several hotel room types, facilities and al so the services given. Next section is telep hone courtesy. The students need to have $\mathrm{k}$ nowledge about telephoning since this sect ion covers the followings: telephone courte sy, how to connect the caller and the receiv er, how to take telephone messages, and th e appropriate English expressions related t o them. After providing them with the kno wledge and skills in hotel room types and $t$ elephoning, the students will be given the 1 ast section that covers making room reserv ation. They will learn how to make room $r$ eservation including the appropriate expres sions in English. Furthermore, this section will also review the hotel room types and $\mathrm{t}$ elephoning.

In the second semester, the materia ls given covers check in/out the guests and asking and giving information. Asking and giving information emphasized in this sem ester is asking and giving direction inside a nd outside the building. Check in/out the $\mathrm{g}$ uest is given since the students will handle the guests who will stay or leave the hotel. This is the normal procedure in handling th e guests who wants to stay in the hotel and the materials will cover its appropriate exp ressions in welcoming the guests until esco rting them to the rooms. While for check o ut, the materials will also cover billing and payment expressions in English. The next section is asking and giving direction insid e and outside the hotel. The first part of the materials is asking and giving direction ins ide the hotel that includes location and faci lities of the hotel. The second part deals wi th the facilities around the hotel. These ma terials will cover the notion of direction, lo cation, distance, and so on.

While in the third semester, the mat erials given are asking and giving informat ion, which is directed to information outsid e the hotel: events, festivals, restaurants, to urism places, etc. nearby the hotel. The sec ond material is handling complaint both $\mathrm{sp}$ oken and written. This material is chosen $\mathrm{s}$ ince the guests might feel satisfied with the hotel services or not. Besides, it is also bas ed on the needs of the most students' respo ndent. They said that handling guests' com plaint was very important as it was also sta ted by the hotel FOMs. The material will c over the attitude and also the appropriate e xpressions in handling guests' complaint $b$ oth spoken and written expressions.

\section{Learning Activities}

The learning activities needed are more emphasized in speaking. Based on th e findings, the course activities will includ e class sessions, class discussions, teacher and student's presentation, varied simulati 
ons and appropriate role-play for Room Di vision department in a hotel, midterm, and final exam. Role-play and simulation woul $\mathrm{d}$ be suitable since the students will experi ence the real situation they are going to de al with in the industries, as Chester (1996) mentioned that role play provides the stude nts with a dramatic confrontation and clari fication of the ways in which academic ma terial may be relevant to his daily tasks. Be sides, Huyack (1975) and Teahan (1975) a s cited in Jarvis et al (2002) stated that role -play improves the students' communicati on and interpersonal skills respectively.

\section{Assessment}

Based on the findings, the assessm ent should be more emphasized on oral ass essment since it is related to listening and $\mathrm{s}$ peaking as the most needed English skills $\mathrm{f}$ or Front Office department. Thus, it is assu med that role-play would be suitable for th e oral assessment. Video recording will be taken for role-play to avoid the possibilitie $\mathrm{s}$ of missing the important points to be take $\mathrm{n}$ during the assessment processes. Howev er, written assessment is also needed since it is interrelated to the oral assessment. Cla ss assignments and homework would also be given to the students as well in order to check their understanding and comprehens ion of the material given.

\section{CONCLUSION}

The conclusion can be protrayed $b$ ased on the student's questinnaire and also interview with hotel's FOM and the Englis $\mathrm{h}$ lecture as follows: 1) English language is important and needed in hotel industry, esp ecially for those who have direct contact $\mathrm{w}$ ith the guests. 2) Listening and speaking sk ills have become the major English skill th at should be possessed by those who work as the front liners since they need to have a good communication skill in order to com municate well with the guests. 3) Job kno wledge of the front liners, good communic ation skills, good grooming of attitude and appearance, enthusiasm, politeness and fri endliness also become the basic skills for $\mathrm{f}$ ront liners in the Front Office. 4) Innovatio $\mathrm{n}$ in teaching and learning of English, spec ific English materials related to the job des cription of front liners and also native spea ker are strongly suggested to enhance the s tudent's ability in speaking English. 5) Ora 1 test as one of the assessment of English is strongly suggested to encourage the studen t's self-confidence in speaking English.

\section{ACKNOWLEDGEMENT}

This study could not have been finished without encouragement and help of many people. Therefore, we would like to thank and appreciate them deeply. Our gratitude and appreciation is expressed to the hotel's Font Office Manager, the English lecturer and all fifth semester students of Room Division of Sekolah Tinggi Pariwisata Bandung. We are so grateful to our colleagues at Sekolah Tinggi Pariwisata Bandung for their kind support, especially Pak Djoko for proofreading our study in the middle of his busy schedule.

\section{REFERENCES}

Blue, G.M., and Harun,M. 2003. Hospitality Language as A professional Skill, English for Specific Purposes 22 p.73-91. Available at www.elsevier.com/locate/esp (retrieved on May 2013).

Chester, M., Fox, R.1996. Role-Playing Approach Science Research Associates. Available at www.maxwell.syr.edu/plegal/crite/ al.html. (retrieved on September 2013).

Dudley-Evans, T., St John, M.J. 1998. Developments in English for Specific Purposes, Cambridge: Cambridge University Press.

Gatehouse, K., Key Issues in English for Specific Purposes (ESP) 
Curriculum Development.

Available at

http://iteslj.org/Article/Gatehouse-

ESP.html (retrieved on January 2010).

Hutchinson, T., Waters, A. 1995.English for Specific Purposes, Melbourne: Cambridge University Press.

Jarvis, L, et al. 2002. Role-Playing as a Teaching Strategy. Available at www.imet.csus.edu (retrieved on September 2013).

Kappa M.M, et al. 1990. American Hotel \& Motel Association, Michigan: Educational Institute.

Kaur, S. 2007. ESP: Course Design: Matching Learner Needs to Aims. English for Specific Purposes World Online Journal for Teachers Issue 1(14), Volume 6, 2007. Available at http://www.espworld.info/Articles 14/DESIGNIN G\%20ESP\%20COURSES.htm (retrieved on January 12, 2012).

Krahnke, K.1987. Approaches to Syllabus Design for Foreign Language Teaching, New Jersey: PrenticeHall, Inc.

Nunan, D.1989. Syllabus Design. Oxford: Oxford University Press.

Richards, J.C., Rodgers, T.S. 2001. Approaches and Methods in Language Teaching, Cambridge: Cambridge University Press.

Songhori, M.H.2008. Introduction to Needs Analysis. English for Specific Purposes World, issue 4. Available at www.wsp-world.info. (retrieved on January 2010)

Weissinger, S.S. 2000. Hotel/Motel Operations an Overview $2^{\text {nd }}$ edition, Canada: Delmar Thomson Learning. 